\title{
ECONOMIC EFFECTS OF IRRIGATION OF BASIC FIELD CROPS ON FAMILY FARMS
}

\author{
Mihajlo Munćan ${ }^{1}$ \\ *Corresponding author E-mail: mmuncan@agrif.bg.ac.rs
}

A R T I C L E I N F O
Review Article
Received: 20 March 2018
Accepted: 24 May 2018
doi:10.5937/ekoPolj1802787M
UDC 330.131:[631.67:631.11]

Keywords:

irrigation, field crop farming, family farms, economic effects

JEL: Q12, Q15

\section{A B S T R A C T}

The main objective of the research presented in this paper is to assess the economic impact of the application of irrigation in the production of basic field crops (maize, sunflower, soybean and sugar beet) on family farms operating in the South Banat area. Based on the data collected from the survey conducted on 75 family farms specialized in market oriented production without irrigation, using the method of models, calculation and comparison of the obtained results, an assessment was made of the economic impact of the application of irrigation in the production of basic field crops, as well as the assessment of their business performance. It has been established that the most significant economic impact from the application of irrigation in the production of basic field crops can be achieved on farms with 10-20 ha of arable land. Gross margins per hectare of arable land, depending on the type of soil prevailing in the holding, increased from $87 \%$ to $146 \%$, while income per active member of the family farm dealing exclusively with agriculture could double.

(C) 2018 EA. All rights reserved.

\section{Introduction}

Precipitation is the main source of water for both soil and plants. The major importance of precipitation for plants is in the vegetation period when they are especially vulnerable to water deficit. This period is called the critical period, and the lack of precipitation during this period reflects to a large extent on the yield level. The analysis of atmospheric precipitation in Vojvodina, in the period 1972 - 2011, carried out by Munćan. M. (2016) states that of the 40 examined years, 11 years were with an annual precipitation level of below $500 \mathrm{~mm}, 6$ years with an annual sum of precipitation of $500-550 \mathrm{~mm}$ and 4 years under $600 \mathrm{~mm}$. Despite the average $604 \mathrm{~mm}$ precipitation in Vojvodina, in the observed forty years, due to unfavourable distribution and strong evaporation, especially in the summer months, there is a lack of water required for field crop cultivation.

1 Mihajlo Munćan, Ph.D., Assistant Professor, University of Belgrade, Faculty of Agriculture, Nemanjina 6, 11080 Zemun, Serbia, Phone: +381 11 4413416, e-mail: mmuncan@agrif.bg.ac.rs 
The moisture deficit is especially pronounced in the summer months of July, August and September, when the air temperature is the highest, relative air humidity is the lowest, and evapotranspiration is very high. Considering that about $60 \%$ or about $370 \mathrm{~mm}$ of the average annual amount of precipitation in Vojvodina occurs in the period of vegetation (April-September), and taking into account that the total water requirements of field crops in this period, according to the research results of numerous authors (Maksimović, Dragović, 2002; Glamočlija, 2004; Pejić, 2008; Tabaković, 2012; Bojović, 2014) are as follows: wheat about $200 \mathrm{~mm}$, maize 430-540, sunflower 350-500 mm, soybean 380-545 and sugar beet $560 \mathrm{~mm}$, it can be concluded that the production of field crops in the area of Vojvodina is very much affected by the lack of water. Occasional droughts, such as those in $1973,1983,1988,1990,1993,2000,2002$, and 2012, have inflicted heavy damage to agriculture. According to the data of the Statistical Office of the Republic of Serbia, in Vojvodina, year 2000 was characterized by the lowest annual precipitation of only 277 $\mathrm{mm}$, of which only $143 \mathrm{~mm}$ during the vegetation period, the average yields were very low, amounting to: wheat $2.98 \mathrm{t} / \mathrm{ha}$, maize $2.82 \mathrm{t} / \mathrm{ha}$, sunflower $1.42 \mathrm{t} / \mathrm{ha}$, soybean $1.15 \mathrm{t} / \mathrm{ha}$ and sugar beet $22.54 \mathrm{t} / \mathrm{ha}$. In year 2012, the average wheat yield was $2.01 \mathrm{t} / \mathrm{h}$, maize 3.34 $\mathrm{t} / \mathrm{ha}$, sunflower $1.82 \mathrm{t} / \mathrm{ha}$, soybean $1.52 \mathrm{t} / \mathrm{ha}$ and sugar beet $28.49 \mathrm{t} / \mathrm{ha}$. By the correlation and regression analysis it was established that the application of mineral fertilizers and atmospheric precipitation during the vegetation period had statistically significant or very significant impact on the level of realized yields of basic field crops on the family farms in the Vojvodina region, in the period 1972-2011 year (Munćan, 2016).

The greatest share of field crop production in the Republic of Serbia is realized in the Vojvodina region. About $52 \%$ of the total area under cereals and over $92 \%$ of area under industrial plants are planted in this area (Bošnjak, Rodić, 2010). Family farms represent the most important carriers of the organization of field crop production in Vojvodina. According to the 2012 Agricultural Census, the number of these farms in Vojvodina amounted to 146,269 , which makes $23.3 \%$ of the total number of holdings/farms in the Republic of Serbia. In the ownership structure of the farms in the Vojvodina region, farms of over 10 hectares make $21.5 \%$ of the total number of farms and utilize $77.5 \%$ of the arable land. The results of the Agricultural Census have directed the focus of these surveys on family farms of over 10 ha of size.

The subject of the research presented in this paper is the production of basic field crops with the use of irrigation on the family farms of Vojvodina. The main objective of the research is to assess the economic impact of irrigation in the production of basic field crops (wheat, maize, sunflower, soybean and sugar beet) on family farms of Vojvodina.

Starting from the subject matter, and taking into account the set goal of the research, the basic hypothesis of this work is: the application of irrigation can be used in the function of increasing the economic effects of the production of basic field crops and achieving better business results and operation performance of family farms. 


\section{Materials and methods}

The data collected by the survey of 75 family farms, focusing exclusively on field crop production from the South Banat ${ }^{2}$ area, was used as the primary data source. The South Banat region was put in the focus of this research because of the results of the 2012 Census of Agriculture showing that this area, in comparison with other areas of the Vojvodina region, it is characterized by the following: greater share in the total used agricultural and arable land, and in the total number of family holdings/farms; greater share of basic field crops in the sowing structure of the arable land of family farms and larger number of family farms of 10-100 ha and their share in the total volume of production of basic field crops of the region of Vojvodina. The survey of family farms focusing exclusively on field crop production in the South Banat area, in the period 2011-2014, was used as the material for this research. The survey covers family farms of 10-100 ha of arable land and five basic field crops (maize, wheat, sunflower, soybean and sugar beet), which are regarded as basic/essential because of the fact that, in the period of the survey 2011-2014, they represented on average annually $86 \%$ of the arable land of family farms of this area. All surveyed family farms, from the territory of the South Banat region, were classified according to the size of the area of used arable land in three range groups (10-20 ha, 20-50 ha and 50-100 ha).

Based on the representation of certain types, subtypes and soil varieties in the pedological map of Vojvodina (Živković et al., 1972), all surveyed family farms were classified in two variants:

- $\quad$ Variant I - family farms with prevalent soil of chernozem carbonate type on the wood panel (45 family farms surveyed);

- $\quad$ Variant II - family farms dominated by marsh smonitsa type soil (30 family farms surveyed).

When calculating the value indicators, the four-year (2011-2014) average prices realized by the surveyed family farms were used. Average prices were used in order to avoid the extreme effects of natural conditions on outputs achieved in certain years, as well as the annual fluctuations in the price of inputs and outputs resulting from distorted market relations.

The selection of research methodology has been harmonized with the subject of research on one and the volume and quality of data, on the other hand. Since research issues are primarily of an organizational and economic nature and that the subject of research is the organizational, i.e. the production system, on which experiments cannot be conducted, the general method applied in this paper was a modelling method. The models allow agricultural producers to analyse their current and expected situation

2 Area is a statistical functional territorial unit, established for the purposes of planning and implementing regional development policy, in accordance with the nomenclature of statistical territorial units at level 3, is not an administrative territorial unit and has no legal subjectivity; Law on Regional Development "Official Gazette of RS” No. 51/09. 
in the future, gain a better insight into problems, find solutions to specific problems in the future and perceive their consequences so that they can act in accordance with possible alternatives, or make the right choice which, in their opinion, is the optimal for the given situation (Todorović, 2008). In addition to the method of model, the method of calculation and method of comparison of the achieved results were used for the estimation of the economic effects of the application of irrigation in the production of basic field crops, and the results of the research are presented in les and graphs.

\section{Research results and discussions}

Irrigation is a part of the complex modern agro-practice of cultivating agricultural plants and obtaining high yields. According to study by Stojković, L., from year 1954, in Vojvodina, the irrigation eliminates the unfavourable effect of longer or shorter dry periods, and the crops are supplied with water to the optimal needs. In soil that is irrigated, organic matter decomposes faster, plant nutrients are activated faster and more intensively and are used to a greater extent by the crops, the weeds on irrigated soils develop faster and more efficiently, after irrigation, a surface soil layer is created, which contributes to some extent to the diminishing of the soil structure. Therefore, in the irrigation conditions, the intensive fertilization by mineral and organic fertilizers should compensate for the utilized nutrient reserves, which is confirmed by the results of numerous studies (Babović et al., 2004; Grujančić et al., 2008; Maksimović et al., 2010) according to which timely application of adequate quantities of mineral nutrients is necessary in order to achieve high, good quality, stable and economically justified yields of field crops by using irrigation. By frequent and impeccable cultivation, crops must be kept free of weeds, and the soil structure must be constantly repaired and maintained by proper basic treatment and appropriate crop rotation. If these settings are not sufficiently accounted for, after a few successful years, at the beginning of the application, the irrigation will lead to unintended consequences, that is, to the exhaustion of the soil and destruction of its structure.

The mentioned facts stipulated that when constructing a model of family farms, it was assumed that the maximum effects of soil utilization, genetic potential of cultivated plants and irrigation application can only be expected if an appropriate amount of mineral fertilizers was applied.

In Serbia, irrigation systems, according to the 2012 Census of Agriculture, covered 85,593 hectares of land, of which a total of 53,086 hectares were irrigated. The share of irrigated area in relation to the total agricultural land used in 2012 was around 1\%, which is the lowest in Europe. The most common type of irrigation is irrigation by artificial rain. Of the total irrigated area, 93\% is irrigated using the artificial rain, $1 \%$ is irrigated by superficial irrigation, and by drip irrigation $6 \%$ of the area. These statistical indicators have determined the selection of irrigation systems that will be used in the construction of models in this study. Namely, in order to construct a model of family farms that apply irrigation, the self-propelled rain cannon (typhoon) irrigation system was selected. This irrigation system, despite its high energy consumption per work 
time, requires the lowest investment and is especially suitable for use on small plots (Potkonjak, Mačkić, 2010). By using a self-propelled rain cannon, in relation to the linear mobile system and the mobile rain wing, cultivated field crops give the highest yields, and the arrangement of the water sediment is most balanced (Miodragović, 2009). Based on the above said, as well as on the conditions in the field where the surveyed family farms operate, for each variant an irrigation system was designed.

The irrigation system in variant I consisted of a water catchment which involved digging and equipping wells (according to the experimental data collected on the surveyed area, the depth is about 50 meters), the installation of a primary pipeline with filtration (diesel pump, polyethylene hoses and a sand separator), the installation of a secondary pipeline (hydrant networks) and supply of water distributor (self-propelled rain cannon - typhoon). Total investment in such a system, including preparatory works (cleaning of the ground and marking of the pipeline route, earth and construction works), is amounted to $3,604,800$ RSD (Table 1).

In variant II, the irrigation system is somewhat less expensive. In the immediate vicinity of the largest number of parcels, there is a built canal network for drainage and irrigation. As this system did not require digging and equipping wells, the total investment included: preparatory work, installation of a primary pipeline (diesel pump, polyethylene hoses), a secondary pipeline (hydrant networks) and the purchase of a water distributor (selfpropelled rain cannon) and amounted to 3,058,800 RSD (Table 1).

Table 1. Investment in the irrigation systems

\begin{tabular}{|l|c|c|}
\hline \multicolumn{1}{|c|}{ Elements and type of cost } & Variant I & Variant II \\
\hline Preparation works, RSD & 15,300 & 15,300 \\
\hline Earth and concrete works, RSD & 37,500 & 37,500 \\
\hline Water catchment - equipping, RSD & $1,320,000$ & 894,000 \\
\hline Main pipeline with filtration, RSD & 192,000 & 72,000 \\
\hline Secondary system, RSD & 240,000 & 240,000 \\
\hline Water distributor, RSD & $1,800,000$ & $1,800,000$ \\
\hline Purchase value, RSD & $3,604,800$ & $3,058,800$ \\
\hline Projected irrigation capacity, ha/year & 20 & 20 \\
\hline Value of investment in RSD/ha & $\mathbf{1 8 0 , 2 4 0}$ & $\mathbf{1 5 2 , 9 4 0}$ \\
\hline Planned life span, years & 20 & 20 \\
\hline - Depreciation, RSD/ha per year & 9,012 & 7,647 \\
\hline - Interest costs, RSD/ha per year & 1,918 & 1,914 \\
\hline - Cost of investment maintenance, RSD/ha per year & 600 & 600 \\
\hline Fixed costs, RSD/ha per year & $\mathbf{1 1 , 5 3 0}$ & $\mathbf{1 0 , 1 6 1}$ \\
\hline
\end{tabular}

Source: Calculation by the author based on data collected in the survey

The variable costs of using such dimensioned systems, for the projected system performance of 0.18 ha per hour, which include fuel, oil and lubricants for the diesel pump, the cost of operation of the tractor $20 \mathrm{kN}$ for transportation and system setup (Table 2) are $194 \mathrm{RSD}$ for $10,000 \mathrm{~m}^{3} /$ ha (watering/irrigation standard $1 \mathrm{~mm} / \mathrm{m}^{2}$ ). 
Table 2. Variable costs of using a self-propelled rain cannon (RSD per $\mathrm{mm} / \mathrm{m} 2$ )

\begin{tabular}{|l|c|c|c|c|}
\hline \multirow{2}{*}{\multicolumn{1}{|c|}{ Elements and type of cost }} & \multicolumn{4}{c|}{ Per working hour } \\
\cline { 2 - 5 } & Unit & Quantity & Price (RSD) & Amount (RSD) \\
\hline - The fuel for the pump & 1 & 1.11 & 132 & 147 \\
\hline - Oil and lubricants & 1 & 0.014 & 280 & 4 \\
\hline - Daily technical maintenance & $\mathrm{h}$ & 0.014 & 300 & 4 \\
\hline - Tractor costs 20 kN & $\mathrm{h}$ & 0.027 & 1,401 & 39 \\
\hline Variable costs & & & & $\mathbf{1 9 4}$ \\
\hline
\end{tabular}

Source: Calculation by the author based on data collected in the survey

The analysis of atmospheric precipitation in the area of Vojvodina, in the period from 1972 to 2011, showed that the maize, sugar beet, soybean and, to some extent, sunflower crops are most often endangered by water deficit (Table 3). Wheat crop, both variants, cultivated on surveyed farms exclusively as winter crop, was supplied with sufficient amounts of water from atmospheric precipitation, especially in June, which was also registered as a month with the highest rainfall in the period of vegetation, (average precipitation in the observed forty year period was $87.4 \mathrm{~mm} / \mathrm{m}^{2}$ ), so further research does not anticipate the use of irrigation.

Table 3. The requirements of field crops, average precipitation and water deficit in Vojvodina

\begin{tabular}{|l|c|c|c|}
\hline Crop & $\begin{array}{c}\text { Water requirement } \\
\left(\mathbf{m m} / \mathbf{m}^{2}\right) \text { of plants } \\
\text { in the period of } \\
\text { vegetation }\end{array}$ & $\begin{array}{c}\text { Average precipitation } \\
\text { requirement }\left(\mathbf{m m} / \mathbf{m}^{\mathbf{2}}\right) \text { in the } \\
\text { period of vegetation }(\mathbf{y e a r} \\
\mathbf{1 9 7 2 - 2 0 1 1})\end{array}$ & $\begin{array}{c}\text { Water requirement } \\
\left(\mathbf{m m} / \mathbf{m}^{2}\right) \text { compensated } \\
\text { by irrigation }\end{array}$ \\
\hline Maize & 490 & 370 & 120 \\
\hline Sunflower & 450 & 370 & 80 \\
\hline Sugar beet & 550 & 370 & 180 \\
\hline Soybean & 470 & 370 & 100 \\
\hline
\end{tabular}

Source: Calculation by the author based on previous research studies

Based on the identified water deficit and the projected variable costs of using the irrigation system and the surface of each crop in the structure of the sowing, the costs of irrigation of basic field crops on the surveyed family farms were calculated, according to the groups of farms, both variants (Table 4).

Table 4. Variable costs of irrigation of crops on different size of farm (RSD)

\begin{tabular}{|l|c|c|c|c|c|c|}
\hline \multirow{2}{*}{ Crop } & \multicolumn{3}{|c|}{ Size of the farm (ha), variant I } & \multicolumn{3}{c|}{ Size of the farm (ha), variant II } \\
\cline { 2 - 7 } & $\mathbf{1 4 . 7}$ & $\mathbf{3 6 . 9}$ & $\mathbf{7 8 . 2 9}$ & $\mathbf{1 4 . 7}$ & $\mathbf{3 6 . 9}$ & $\mathbf{7 8 . 2 9}$ \\
\hline Maize & 158,451 & 396,825 & 86,9452 & 124,298 & 277,173 & 492,546 \\
\hline Sunflower & 57,773 & 115,237 & 282,541 & 28,034 & 85,498 & 202,130 \\
\hline Sugar beet & - & 37,986 & 117,321 & - & - & - \\
\hline Soybean & - & - & - & 65,634 & 157,986 & 417,425 \\
\hline
\end{tabular}

Source: Calculation by the author based on data collected in the survey 


\section{The effects of irrigation of field crops}

In order to assess the economic effects of irrigation, first the yields were evaluated based on the results of research by numerous authors (Dragović, 1994; Maksimović, 1999; Dragović et al., 2001; Bošnjak, 2004; Maksimović et al., 2004; Bošnjak, Pejić, 2004; Dragović et al., 2005; Pejić et al., 2007; Pejić et al. 2010; Kresović et al., 2012; Pejić et al., 2012). The calculation of the costs of irrigation of field crops was based on the estimated water deficit that should be compensated by irrigation and variable costs of using the self-propelled rain cannon.

The increased quantities of mineral fertilizers, due to the application of irrigation and the achievement of higher yields, were calculated based on the results of soil fertility analysis of the types represented and the recommendations of professional agricultural services for optimal use of mineral fertilizers.

Table 5. Changes in yield, variable costs and value of production of basic field crops on family farms by application of irrigation (variant I)

\begin{tabular}{|c|c|c|c|c|c|c|c|c|c|}
\hline \multirow{3}{*}{ Indicators } & \multicolumn{9}{|c|}{ Farm size (ha) } \\
\hline & \multicolumn{3}{|c|}{14.7} & \multicolumn{3}{|c|}{36.9} & \multicolumn{3}{|c|}{78.29} \\
\hline & \begin{tabular}{|c|} 
No \\
irrigation
\end{tabular} & Irrigation & Difference & $\begin{array}{c}\text { No } \\
\text { irrigation }\end{array}$ & Irrigation & Difference & $\begin{array}{c}\text { No } \\
\text { irrigation }\end{array}$ & Irrigation & Difference \\
\hline \multicolumn{10}{|c|}{ Yield (t/ha) } \\
\hline Maize & 7.42 & 12 & 4.58 & 7.76 & 12 & 4.24 & 8.03 & 12 & 3.97 \\
\hline Sunflower & 2.48 & 4 & 1.52 & 2.73 & 4 & 1.27 & 2.86 & 4 & 1.14 \\
\hline Sugar beet & - & - & - & 43.26 & 70 & 26.74 & 46.53 & 70 & 23.47 \\
\hline \multicolumn{10}{|c|}{ Variable costs (RSD/ha) } \\
\hline Maize & 69,412 & 108,914 & 39,502 & 53,751 & 90,644 & 36,893 & 51,288 & 88,226 & 36,938 \\
\hline Sunflower & 54,340 & 78,437 & 24,097 & 40,171 & 62,308 & 22,137 & 37,126 & 59,162 & 22,036 \\
\hline Sugar beet & - & - & - & 121,154 & 182,684 & 61,530 & 110,534 & 167,738 & 57,204 \\
\hline \multicolumn{10}{|c|}{ Production value (RSD/ha) } \\
\hline Maize & 115,752 & 187,200 & 71,448 & 121,056 & 187,200 & 66,144 & 125,268 & 187,200 & 61,932 \\
\hline Sunflower & 86,800 & 140,000 & 53,200 & 95,550 & 140,000 & 44,450 & 100,100 & 140,000 & 39,900 \\
\hline Sugar beet & - & - & - & 166,551 & 269,500 & 102,949 & 179,141 & 269,500 & 90,360 \\
\hline
\end{tabular}

Source: Calculation by the author

The smallest family farms would have the most significant effects from the application of irrigation (Table 5). Namely, the yields and the value of maize and sunflower production on these farms of variant I would increase by $62 \%$ and $61 \%$, respectively. In case of the largest family farms of variant $\mathrm{I}$, this increase would be: in the production of maize $49 \%$, sunflower $40 \%$ and sugar beet by about $50 \%$. At the same time, in case of the farms of all sizes, variable costs would be significantly increased due to the application of irrigation and increased quantities of mineral fertilizers.

The value of the net effect of the production of basic field crops on commercial farms using irrigation calculated as the difference between the increased value of production and the increased variable costs is given in Table 6. 
Table 6. The net effect from the application of irrigation of basic field crops on family farms (variant I)

\begin{tabular}{|l|c|c|c|}
\hline \multicolumn{1}{|c|}{ Crop } & $\begin{array}{c}\text { Increased variable costs } \\
\text { (RSD/ha) }\end{array}$ & $\begin{array}{c}\text { Increased production } \\
\text { value (RSD/ha) }\end{array}$ & $\begin{array}{c}\text { Difference } \\
\text { (RSD/ha) }\end{array}$ \\
\hline Farm size, 14.7 ha & 39,502 & 71,448 & 31,946 \\
\hline Maize & 24,097 & 53,200 & 29,103 \\
\hline Sunflower & 36,893 & 66,144 & 29,251 \\
\hline Farm size, 36.9ha & 22,137 & 44,450 & 22,313 \\
\hline Maize & 61,530 & 102,949 & 41,419 \\
\hline Sunflower & 36,938 & 61,932 & 24,994 \\
\hline Sugar beet & 22,036 & 39,900 & 17,864 \\
\hline Farm size, 78.29 ha & 57,204 & 90,360 & 33,156 \\
\hline Maize & \multicolumn{5}{|l}{} \\
\hline Sunflower & Sugar beet &
\end{tabular}

Source: Calculation by the author

The greatest net effect from the application of irrigation on crop cultivation was also realized on the smallest family farms, slightly less on farms of 20-50 ha, while the least effects were realized on the largest farms of the size of 50-100 ha.

Farms of the variant II were similar to variant I. The most significant effects of irrigation were realized on family farms of 10-20 ha, and the least effects on the farms of 50-100 ha (Table 7).

Table 7. Changes in yield, variable costs and value of production of basic field crops on family farms by application of irrigation (variant II)

\begin{tabular}{|c|c|c|c|c|c|c|c|c|c|}
\hline \multirow{3}{*}{ Indicators } & \multicolumn{9}{|c|}{ Farm size (ha) } \\
\hline & \multicolumn{3}{|c|}{14.7} & \multicolumn{3}{|c|}{36.9} & \multicolumn{3}{|c|}{78.29} \\
\hline & \begin{tabular}{|c|} 
No \\
irrigation
\end{tabular} & Irrigation & Difference & \begin{tabular}{|c|} 
No \\
irrigation
\end{tabular} & Irrigation & Difference & \begin{tabular}{|c|} 
No \\
irrigation
\end{tabular} & Irrigation & Difference \\
\hline \multicolumn{10}{|l|}{ Yield (t/ha) } \\
\hline Maize & 5.96 & 12 & 6.04 & 6.21 & 12 & 5.79 & 6.48 & 12 & 5.52 \\
\hline Sunflower & 2.38 & 4 & 1.62 & 2.42 & 4 & 1.58 & 2.61 & 4 & 1.39 \\
\hline Soybean & 2.58 & 4 & 1.42 & 2.83 & 4 & 1.17 & 3.18 & 4 & 0.82 \\
\hline \multicolumn{10}{|c|}{ Variable costs (RSD/ha) } \\
\hline Maize & \begin{tabular}{|l|}
69,586 \\
\end{tabular} & 110,608 & 41,022 & 55,676 & 91,329 & 35,653 & 51,745 & 86,611 & 34,866 \\
\hline Sunflower & 60,951 & 85,542 & 24,591 & 45,287 & 68,053 & 22,766 & 42,532 & 63,504 & 20,972 \\
\hline Soybean & 65,775 & 89,477 & 23,702 & 116,030 & 71,024 & 22,270 & 41,869 & 63,790 & 21,921 \\
\hline \multicolumn{10}{|c|}{ Production value (RSD/ha) } \\
\hline Maize & 92,976 & 187,200 & 94,224 & 96,876 & 187,200 & 90,324 & 101,088 & 187,200 & 86,112 \\
\hline Sunflower & 83,300 & 140,000 & 56,700 & 84,700 & 140,000 & 55,300 & 91,350 & 140,000 & 48,650 \\
\hline Soybean & 105,780 & 164,000 & 58,220 & 48,754 & 164,000 & 47,970 & 130,380 & 164,000 & 33,620 \\
\hline
\end{tabular}

Source: Calculation by the author

The calculated net effect of intensifying the production of basic field crops (Table 8) showed that the application of irrigation was fully economically justified in all groups of farms of variant II. 
Table 8. The net effect from the application of irrigation of basic field crops on family farms (variant II)

\begin{tabular}{|l|c|c|c|}
\hline \multicolumn{1}{|c|}{ Crop } & $\begin{array}{c}\text { Increased variable costs } \\
\text { (RSD/ha) }\end{array}$ & $\begin{array}{c}\text { Increased production } \\
\text { value (RSD/ha) }\end{array}$ & $\begin{array}{c}\text { Difference } \\
\text { (RSD/ha) }\end{array}$ \\
\hline Farm size, 14.7 ha & \multicolumn{5}{|c|}{} \\
\hline Maize & 41,022 & 94,224 & 53,202 \\
\hline Sunflower & 24,591 & 56,700 & 32,109 \\
\hline Soybean & 23,702 & 58,220 & 34,518 \\
\hline Farm size, 36.9ha & 35,653 & 90,324 & 54,671 \\
\hline Maize & 22,766 & 55,300 & 32,534 \\
\hline Sunflower & 22,270 & 47,970 & 25,700 \\
\hline Soybean & 34,866 & 86,112 & 51,246 \\
\hline Farm size, 78.29 ha & 20,972 & 48,650 & 27,678 \\
\hline Maize & 21,921 & 33,620 & 11,699 \\
\hline Sunflower & \multicolumn{5}{|l}{} \\
\hline Soybean &
\end{tabular}

Source: Calculation by the author

The most significant increase in the gross margin per hectare of arable land by application of irrigation in the production of basic field crops was realized on the smallest family farms, in case of variant I it was $87 \%$, and variant II, this increase was $146 \%$. Contrary to small farms, a significantly higher level of intensity, which was realized on farms of 50-100 ha, recorded significantly lower effects from the application of these measures - 32\% for farms of variant I and 43\% for variant II (Figure 1).

Figure 1. Gross margin per hectare of surveyed farms before and after the application of irrigation

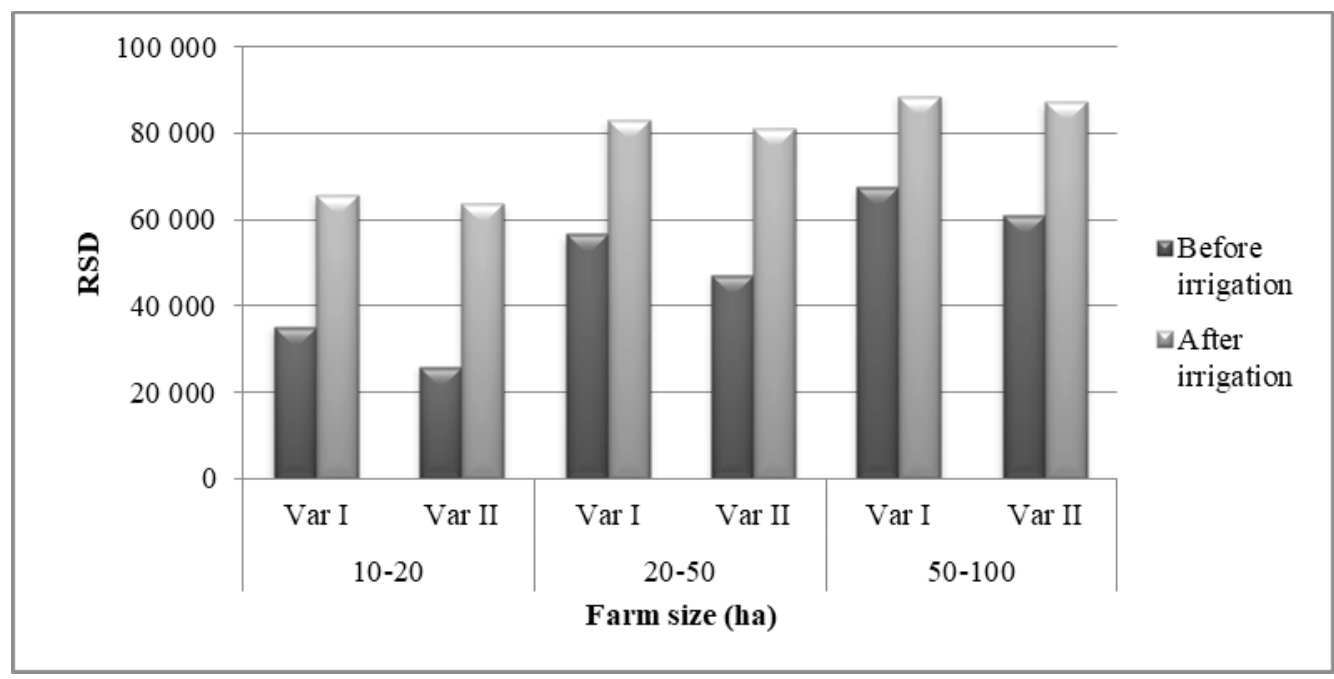

Source: Calculation by the author 
The impact of irrigation expressed in terms of income per unit of area and by an active member of the household engaged exclusively in agriculture resulted in an increase of $74 \%$ on the smallest family farms of variant I and more than two and a half times on the smallest farms of variant II. On the largest family farms, the application of irrigation showed moderate increase of these indicators, especially in case of farms of the variant I $-21 \%$, while in case of farms of the variant II this increase was $41 \%$ (Figure 2, Figure 3).

Figure 2. Income per hectare of surveyed farms, before and after application of irrigation

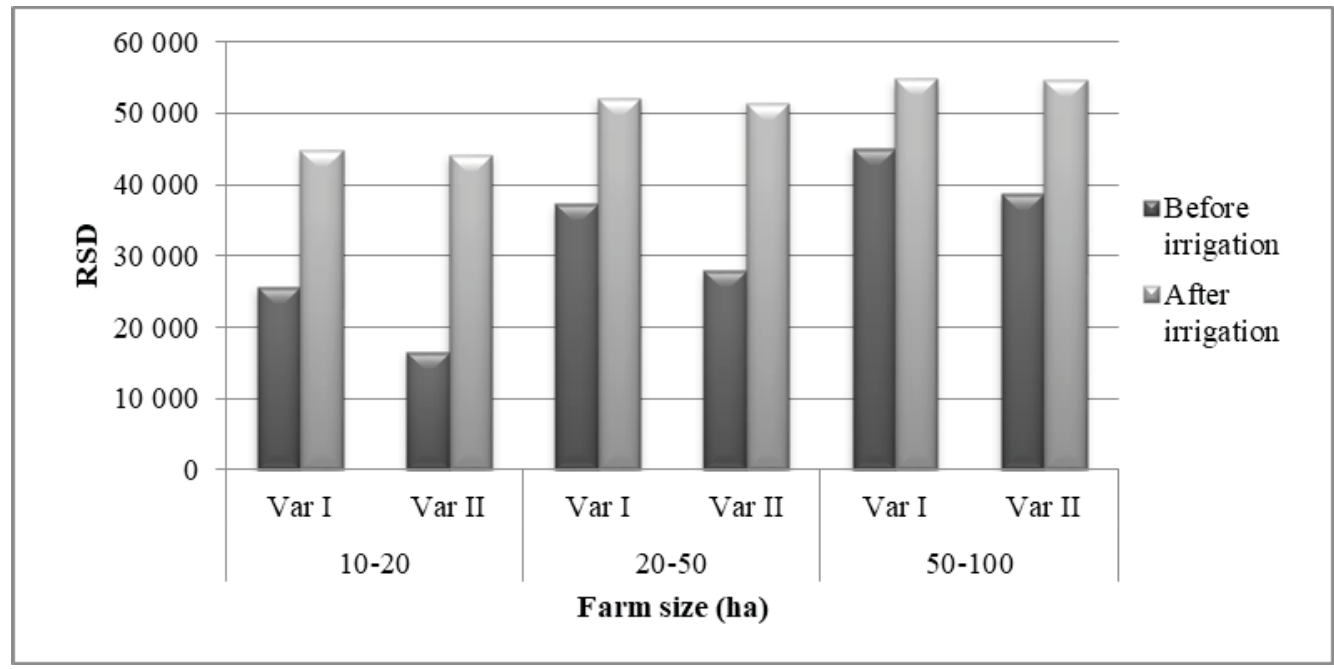

Source: Calculation by the author

Figure 3. Income per active member of the surveyed farms before and after application of irrigation

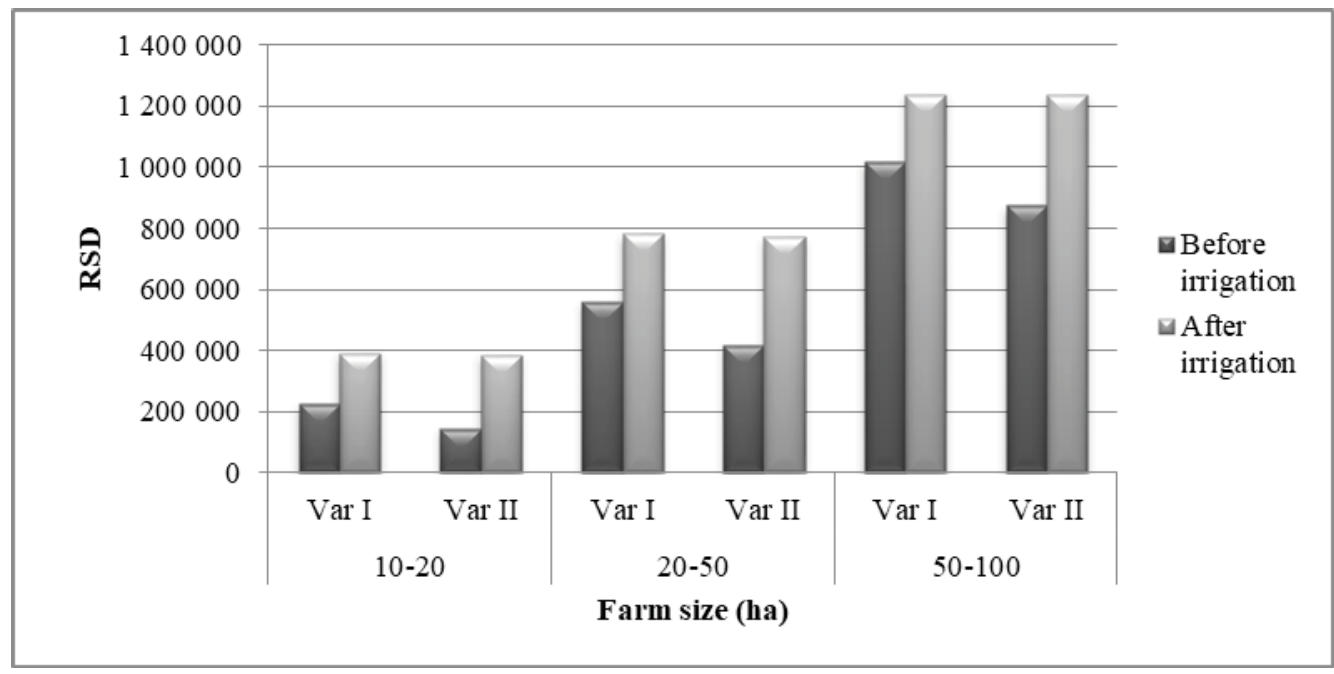

Source: Calculation by the author 


\section{Conclusion}

The derived economic indicators fully confirmed the initial hypothesis that the application of irrigation can be successfully used in the function of increasing the economic effects of the production of basic field crops and achieving better operating results of the family farm business. Considering that the smallest family farms (size 10$20 \mathrm{ha}$ ), due to their economic strength and technical equipment, apply a significantly lower level of intensity in the production of basic field crops, compared to family farms of 50-100 ha, the greater possibilities for increasing the economic effects from the application of irrigation were recorded on these farms. Namely, by applying irrigation on family farms size of $10-20$ ha, the yield of maize would increase from $62 \%$ to $101 \%$, while the sunflower yield would increase from $61 \%$ to $70 \%$ depending on the type of soil. Also, the gross margin of these farms would increase from $87 \%$ to $146 \%$, while the income per active member of the farm operating exclusively in agriculture could increase from $74 \%$ to $102 \%$.

\section{Acknowledgements}

Paper represents a part of the research on the project „Serbian Rural Labour Market and Rural Economics - Revenue Diversification and Poverty Mitigation”, No. ON179028, financially supported by the Ministry of Education, Science and Technological Development of the Republic of Serbia

\section{Conflict of interests}

The authors declare no conflict of interest.

\section{References}

1. Babović, J., Radojević, V., Radojević, V.V. (2004). The economic benefits of irrigation. Economics of Agriculture, 51(3-4), Institute of Agricultural Economics, Belgrade, 25-38.

2. Bojović, R. (2014). Morphological and productive properties of sugar beet genotypes in conditiones of intensive plant nutrition, Doctoral Dissertation, University of Belgrade-Faculty of Agriculture, Belgrade. [in Serbian: Bojović, R. (2014), Morfološke i proizvodne osobine genotipova šećerne repe u uslovima intenzivne ishrane biljaka].

3. Bošnjak D., Rodić V. (2010). Comparative analysis of the basic field crops production costs in Vojvodina. Economics of Agriculture, 57(2), Institute of Agricultural Economics, Belgrade, 233-243.

4. Bošnjak, Đ.,Pejić, B. (1994): Realizacija racionalnog zalivnog režima kukuruza. A Periodical of Scientific Research on Field and Vegetable Crops, 22, Institute of Field and Vegetable Crops, Novi Sad,167-178. [in Serbian: Bošnjak, Đ., Pejić, B. (1994), Realizacija racionalnog zalivnog režima kukuruza]. 
5. Bošnjak, Đ. (2004). Drought and its relation to field crops production in Vojvodina province. A Periodical of Scientific Research on Field and Vegetable Crops, 40, Novi Sad, Institute of Field and Vegetable Crops, Novi Sad, 45-55. [in Serbian: Bošnjak, Đ. (2004), Suša i njen odnos prema ratarskoj proizvodnji u Vojvodini].

6. Glamočlija, Đ. (2004). Special cropping - cereals and grain legumes. Draganić, Belgrade. [in Serbian: Glamočlija, Đ. (2004), Posebno ratarstvo - žita i zrnene mahunarke].

7. Gujaničić, T., Glamočlija, Đ., Maletić R., Savić J. (2008). Production of sugar beet in conditions of intensive plant nutrition and irrigation of crops. Journal of Scientific Agricultural Research, 69(1), SPITS, Belgrade, 69-78.

8. Dragović, S. (1994). The effect of irrigation in extreme drought years. A Periodical of Scientific Research on Field and Vegetable Crops, 22, Institute of Field and Vegetable Crops, Novi Sad, 97-108. [in Serbian: Dragović, S. (1994), Efekat navodnjavanja u ekstremno sušnim godinama].

9. Dragović, S., Maksimović Livija, Škorić, D. (2001). Water requirements of NS sunflower hybrids and impact of irrigation. A Periodical of Scientific Research on Field and Vegetable Crops, 35, Institute of Field and Vegetable Crops, Novi Sad, 403-413. [in Serbian: Dragović, S., Maksimović, L., Škorić, D. (2001), Potrebe za vodom i efekat navodnjavanja NS-hibrida suncokreta].

10. Dragović, S., Maksimović, L., Radojević, V., Cicmil, M., Radojević, V.V. (2005). Impact of irrigation on evapotranspiration and increase of sunflower yield in agroecological conditions of Vojvodina. Acta biologica Iugoslavica series A: Soil and plant, 54(2), Yugoslav Society for Land Survey, Belgrade, 115-124. [in Serbian: Dragović, S., Maksimović, L., Radojević, V., Cicmil, M., Radojević, V.V. (2005), Uticaj navodnjavanja na evapotranspiraciju i povećanje prinosa suncokreta u agroekološkim uslovima Vojvodine].

11. Živković, B.M., Nejgebauer, V.K., Tanasijević, Đ., Miljković, N., Stojković, L., Drezgić, P. (1972). Lend of Vojvodina. Institute for Agricultural Research, Novi Sad. [in Serbian: Živković, B.M., Nejgebauer, V.K., Tanasijević, Đ., Miljković, N., Stojković, L., Drezgić, P. B. (1972), Zemljišta Vojvodine].

12. Kresović, B., Dragičević, V., Gajić, B., Tapanrova, A., Pejić, B. (2012). The effects of use self-propelled rain guns (typhone) in irrigation of corn (Zea mays L.). Agricultural Engineering, 4, University of Belgrade-Faculty of Agriculture, Belgrade, 31-39. [in Serbian: Kresović, B., Dragičević, V., Gajić, B., Tapanrova, A., Pejić, B. (2012), Efekti primene tifon uređaja u navodnjavanju kukuruza (Zea mays L.)].

13. Maksimović, L. (1999). Dependence of yield and morphological characteristics of corn from soil moisture and irrigation system irrigation. Doctoral Dissertation, University of Novi sad-Faculty of Agriculture, Novi Sad. [in Serbian: Maksimović, L. (1999), Zavisnost prinosa i morfoloških karakteristika kukuruza od vlažnosti zemljišta i sistema đubrenja u navodnjavanju]. 
14. Maksimović, L., Dragović, S. (2002). Effect of sugar beet irrigation in different environmental growing conditions. A Periodical of Scientific Research on Field and Vegetable Crops, 36, Institute of Field and Vegetable Crops, Novi Sad, 4356. [in Serbian: Maksimović, L., Dragović, S. (2002), Efekat navodnjavanja šećerne repe u različitim ekološkim uslovima gajenja].

15. Maksimović, L., Jocković, Đ., Dragović, S. (2004). Growing irrigated maize as an important factor in production advancement and stability. A Periodical of Scientific Research on Field and Vegetable Crops, 40, Institute of Field and Vegetable Crops, Novi Sad, 257-268. [in Serbian: Maksimović, L., Jocković, Đ., Dragović, S. (2004), Gajenje kukuruza u navodnjavanju značajan činilac unapređenja i stabilnosti proizvodnje].

16. Maksimović, L., Babović, J., Carić, M. Milić, S. (2010). The economic effects of irrigation and dunging in the sugar-beet production. Economics of Agriculture, 57(4), Institute of Agricultural Economics, Belgrade, 611-623.

17. Miodragović, R. (2009). Optimizing the application of mobile irrigation systems for plant production. Doctoral Dissertation, University of Belgrade-Faculty of Agriculture, Belgrade. [in Serbian: Miodragović, R. (2009), Optimizacija primene mobilnih sistema navodnjavanja u biljnoj proizvodnji.].

18. Munćan, M., (2016). The impact of mineral fertilization and atmospheric precipitation on yield of field crops on family farms, Economics of Agriculture, 63(3), Institute of Agricultural Economics, Belgrade, 817-833.

19. Pejić, B., Maksimović, L., Milić, S. (2007). The effect of irrigation on yield of corn hybrids from different groups of ripening. Acta biologica Iugoslavica - series A: Soil and plant, 56(2), Yugoslav Society for Land Survey, Belgrade, 59-66. [in Serbian: Pejić, B., Maksimović, L., Milić, S. (2007), Efekat navodnjavanja na prinos hibrida kukuruza iz različitih grupa zrenja].

20. Pejić, B., Maksimović, L., Milić, S., Rajić, M., (2010). Effect of irrigation and nitrogen rates on yield and water productivity of sugar beet. Contemporary agriculture, 59(1-2), University of Novi Sad-Faculty of Agriculture, Novi Sad, 1-7.

21. Pejić, B., Bošnjak, Dj., Mačkić, K., Rajić, M., Josipović, M., Jug, I., Maksimović, L., (2012). Yield and water use efficiency of irrigated soybean in the climate conditions of Vojvodina, Serbia. Field and Vegetable Crops Research, 49, Institute of Field and Vegetable Crops, Novi Sad, 80-85

22. Potkonjak, S., Mačkić, K., (2010). Production-economic effects of irrigation with special reference to small plots. Cotemporary Agricultural Engineering, 36(3), University of Novi Sad-Faculty of Agriculture, Novi Sad, 256-266. [in Serbian: Potkonjak, S., Mačkić, K., (2010). Proizvodno-ekonomski efekti navodnjavanja sa posebnim osvrtom na male parcele].

23. Stojković, L. (1954). Crop farming of Vojvodina. Matica srpska, Novi Sad. [in Serbian: Stojković, L. (1954), Ratarstvo Vojvodine]. 
24. Tabaković, M., (2012). Influence of weather conditions, soil and genotypic combinations on the properties of corn hybrid seed. Doctoral Dissertation, University of Belgrade-Faculty of Agriculture, Belgrade. [in Serbian: Tabaković, M., (2012), Uticaj vremenskih uslova, zemljišta i genotipske kombinacije na osobine hibridnog semena kukuruza].

25. Todorović, S., Munćan, M., Ivkov, I., (2008). The significance and role of models in agroeconomic research. Thematic Proceedings - Agroeconomic Sciences and Profession in Transition of Education and Agroeconomy, University of Belgrade-Faculty of Agriculture, Belgrade. [in Serbian: Todorović, S., Munćan, M., Ivkov, I., (2008). Značaj i uloga modela u agroekonomskim istraživanjima]. 